Water Availability and Use Science Program

Prepared in cooperation with the Pajaro Valley Water Management Agency

Detection and Measurement of Land-Surface Deformation, Pajaro Valley, Santa Cruz and Monterey Counties, California, 2015-18

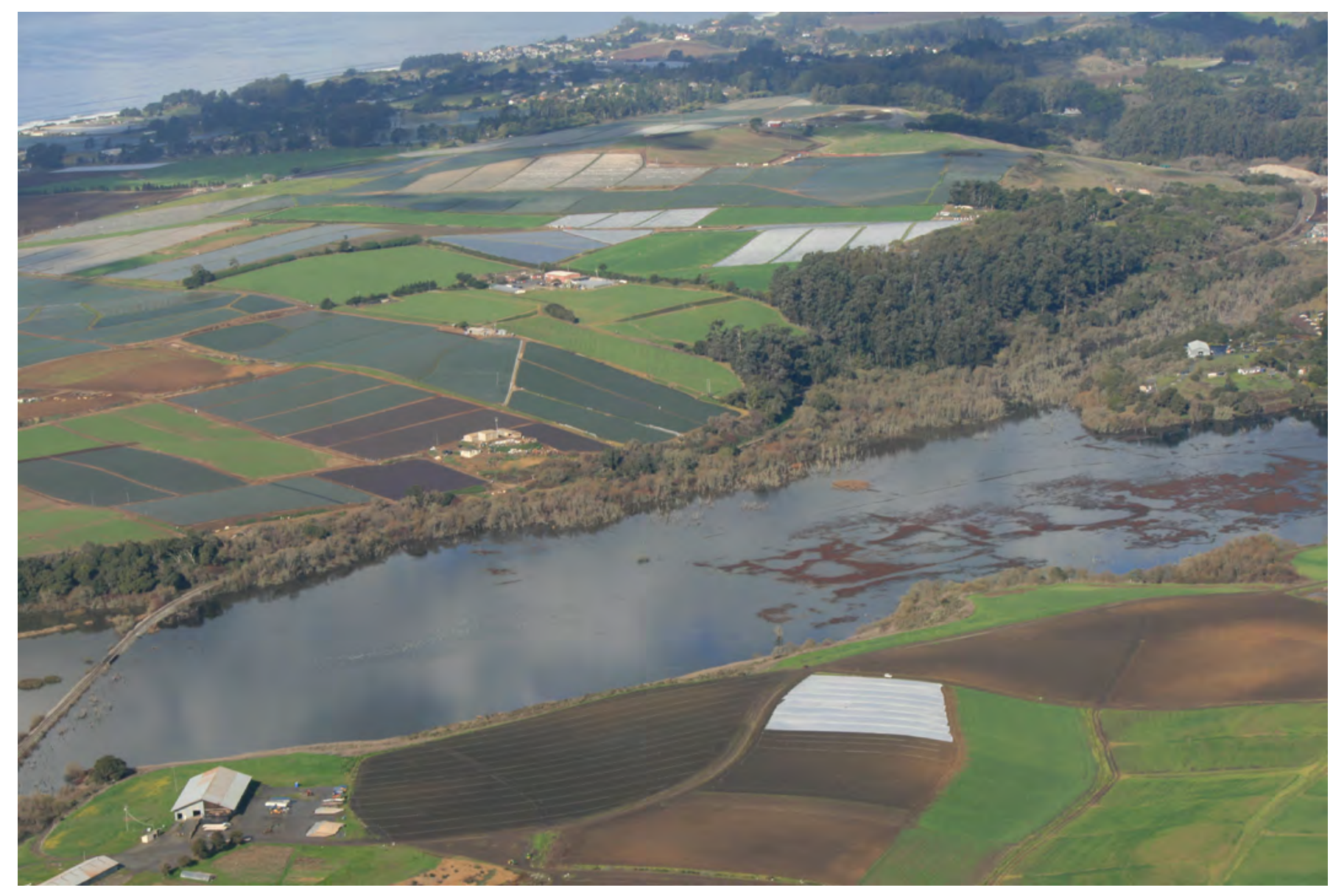

Open-File Report 2021-1101 
Cover: Aerial photograph of Harkins Slough (west of the city of Watsonville) and farm fields in the Pajaro Valley, 2013. Photograph courtesy of the Pajaro Valley Water Management Agency. 


\section{Detection and Measurement of Land-Surface Deformation, Pajaro Valley, Santa Cruz and Monterey Counties, California, 2015-18}

By Justin T. Brandt, Marisa M. Earll, Michelle Sneed, and Wesley Henson

Water Availability and Use Science Program

Prepared in cooperation with the Pajaro Valley Water Management Agency

Open-File Report 2021-1101 


\section{U.S. Geological Survey, Reston, Virginia: 2021}

For more information on the USGS - the Federal source for science about the Earth, its natural and living resources, natural hazards, and the environment—visit https://www.usgs.gov or call 1-888-ASK-USGS.

For an overview of USGS information products, including maps, imagery, and publications, visit https://store.usgs.gov/.

Any use of trade, firm, or product names is for descriptive purposes only and does not imply endorsement by the U.S. Government.

Although this information product, for the most part, is in the public domain, it also may contain copyrighted materials as noted in the text. Permission to reproduce copyrighted items must be secured from the copyright owner.

Suggested citation:

Brandt, J.T., Earll, M.M., Sneed, M., and Henson, W., 2021, Detection and measurement of land-surface deformation, Pajaro Valley, Santa Cruz and Monterey counties, California, 2015-18: U.S. Geological Survey Open-File Report 2021-1101, 16 p., https://doi.org/10.3133/ofr20211101.

Associated data for this publication:

Brandt, J.T., 2021, Interferometric Synthetic Aperture Radar and Water Level Data, Pajaro Valley, Santa Cruz and Monterey Counties, California, 1970-2018, U.S. Geological Survey data release, https://doi.org/10.5066/P9FNAR00.

ISSN 2331-1258 (online) 


\section{Acknowledgments}

The authors gratefully acknowledge the Pajaro Valley Water Management Agency for their support and assistance during this study. We thank the Scripps Orbit and Permanent Array Center for allowing free access to continuous Global Positioning System data. We thank the California Department of Water Recourses for providing free access to Interferometric Synthetic Aperture Radar data through their SGMA Data Viewer. We thank the European Space Agency for their free and open-data policy and the Alaska Satellite Facility for free and open access to their satellite data archives. 



\section{Contents}

Acknowledgments ……...................................................................................................................

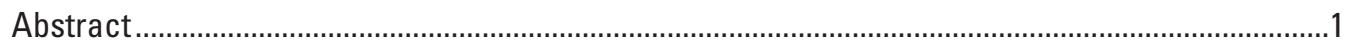

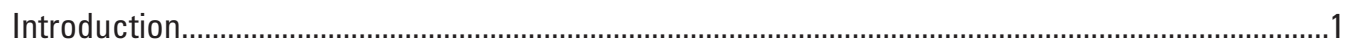

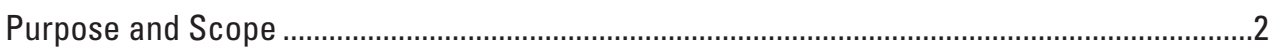

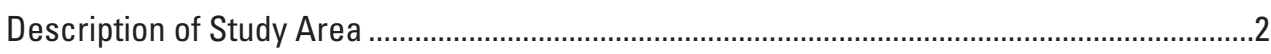

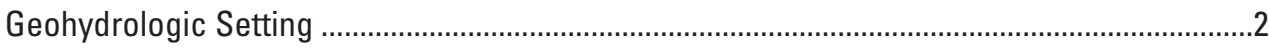

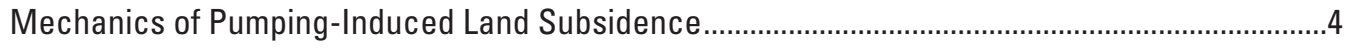

Interferometric Synthetic Aperture Radar (InSAR) ...................................................................

Interferometric Synthetic Aperture Radar Methods …….......................................................

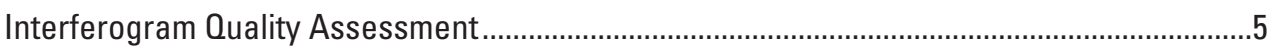

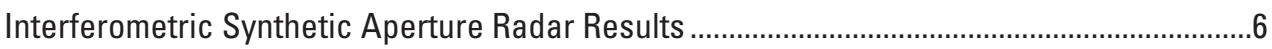

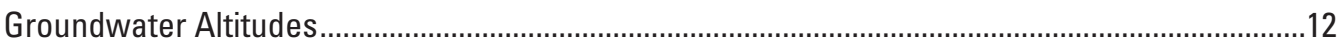

Relation of Geology and Groundwater Altitudes to Land-Surface Deformation.............................13

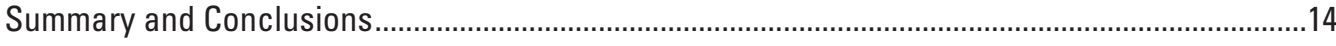

References Cited.................................................................................................................

\section{Figures}

1. Map showing study area of selected continuous Global Positioning System sites, Interferometric Synthetic Aperture Radar time-series locations, wells, and other features, Pajaro Valley, California

2. A simplified illustration of the principle of effective stress as applied to recoverable and permanent compaction of an aquifer system.

3. Graphs showing vertical deformation measured by continuous Global Positioning System and by Interferometric Synthetic Aperture Radar at selected CGPS sites, in Pajaro Valley, California, 2015-18 .................................................7

4. Graphs showing Interferometric Synthetic Aperture Radar time series and groundwater altitudes in Pajaro Valley, California, 2015-18 10

5. Graph showing precipitation and selected groundwater-altitude data in Pajaro Valley, California, water years 1941-2018.

\section{Table}

1. Interferometric Synthetic Aperture Radar interferograms interpreted for Pajaro Valley, California, 2015-18 


\section{Conversion Factors}

U.S. customary units to International System of Units

\begin{tabular}{lcl}
\hline \multicolumn{1}{c}{ Multiply } & By & \multicolumn{1}{c}{ To obtain } \\
\hline inch (in.) & \multicolumn{2}{c}{ Length } \\
inch (in.) & 2.54 & centimeter $(\mathrm{cm})$ \\
foot (ft) & 25.4 & millimeter $(\mathrm{mm})$ \\
mile (mi) & 0.3048 & meter $(\mathrm{m})$ \\
\hline \multicolumn{3}{c}{ Area } \\
\hline square mile $\left(\mathrm{mi}^{2}\right)$ & 259.0 & hectare $(\mathrm{ha})$ \\
square mile $\left(\mathrm{mi}^{2}\right)$ & 2.590 & square kilometer $\left(\mathrm{km}^{2}\right)$ \\
\hline \multicolumn{3}{c}{ Flow rate } \\
\hline inch per year $(\mathrm{in} / \mathrm{yr})$ & 25.4 & millimeter per year $(\mathrm{mm} / \mathrm{yr})$ \\
\hline
\end{tabular}

\section{Datum}

Vertical coordinate information is referenced to the North American Vertical Datum of 1988 (NAVD 88).

\section{Abbreviations}

CDWR California Department of Water Resources

CGPS continuous Global Positioning System

InSAR Interferometric Synthetic Aperture Radar

PV Water Pajaro Valley Water Management Agency

RMSE root mean square error

SAR Synthetic Aperture Radar

SGMA Sustainable Groundwater Management Act

USGS U.S. Geological Survey 


\title{
Detection and Measurement of Land-Surface Deformation, Pajaro Valley, Santa Cruz and Monterey Counties, California, 2015-18
}

\author{
By Justin T. Brandt, ${ }^{1}$ Marisa M. Earll, ${ }^{2}$ Michelle Sneed, ${ }^{1}$ and Wesley Henson ${ }^{2}$
}

\section{Abstract}

Land-surface deformation (subsidence) caused by groundwater withdrawal is identified as an undesirable result in the Pajaro Valley Water Management Agency's Basin Management Plan and California's Sustainable Groundwater Management Act. In Pajaro Valley, groundwater provides nearly 90 percent of the total water supply. To aid the development of sustainable groundwater management criteria, the U.S. Geological Survey, in cooperation with the Pajaro Valley Water Management Agency, performed an analysis of land-surface deformation (subsidence and uplift) in Pajaro Valley for 2015-18, using Interferometric Synthetic Aperture Radar and continuous Global Positioning System methods. Land-surface deformation results were then compared with subsurface geology and groundwater altitudes to better understand the hydromechanical response of the coastal aquifer system. The results indicate the land surface is generally stable with only small magnitudes (less than 1 inch) of seasonal land-surface deformation (subsidence in the summer and uplift in the winter) during 2015-18. During this time, the largest magnitude of land-surface deformation was less than 2 inches of subsidence and was localized in one area just north of the city limits of Watsonville, California. Groundwater altitudes during 2015-18 demonstrated seasonal variability and annual to multi-annual increases after reaching historical lows by the mid-1990s. The small magnitudes of land-surface deformation coupled with groundwater-altitude increases in most areas indicate that the subsidence likely is largely elastic and recoverable. The Corralitos-Pajaro Valley groundwater basin contains fine-grained (clay) sediments that have the potential for permanent aquifer-system compaction and resultant land subsidence. However, groundwater altitudes

${ }^{1}$ U.S. Geological Survey, California Water Science Center, Sacramento, California

${ }^{2}$ U.S. Geological Survey, California Water Science Center, San Diego, California. throughout the Pajaro Valley have increased above historical lows, and observed increases in groundwater altitudes coincided with changes in groundwater management activities. Observed relations between groundwater management activities and groundwater altitudes indicate that management of groundwater supplies could minimize the potential for permanent land-surface deformation in Pajaro Valley.

\section{Introduction}

Land-surface deformation (subsidence) from groundwater extraction in coastal basins has been documented in many areas, including Santa Clara County (fig. 1; Poland and Ireland, 1988), Ventura County (not shown; Hanson and others, 2003), and San Diego, California (fig. 1; Brandt and others, 2020). In Pajaro Valley, groundwater constitutes nearly 90 percent of total water use, and more than 80 percent of total water use is attributed to agricultural land uses; agriculture is a billion-dollar industry for the area (Pajaro Valley Water Management Agency, 2021). Climate variability, population growth, and a shift to more water-intensive crops such as strawberries, bush berries, and vegetable row crops have increased demand of groundwater resources since the 1980s and led to storage depletion, seawater intrusion (from groundwater altitudes declining below sea level based on the North American Vertical Datum of 1988; hereafter referred to as "sea level" for brevity), and overdraft (Hanson and others, 2014). To alleviate these problems, the Pajaro Valley Water Management Agency (PV Water) and stakeholders have worked to develop and implement projects since the mid-1990s that aim to offset groundwater pumping demand and decrease streamflow capture and seawater intrusion. These projects include conservation efforts, managed aquifer recharge, water recycling, and coastal irrigation delivery pipelines to supplement coastal groundwater pumping (Pajaro Valley Water Management Agency, 2014, 2019). 
More recently, PV Water was tasked with developing groundwater sustainability criteria as part of their Basin Management Plan to avoid conditions that lead to long-term overdraft, land subsidence, and water-quality degradation (Pajaro Valley Water Management Agency, 2014). Additionally, California's Sustainable Groundwater Management Act (SGMA) stipulates several "undesirable results" of unsustainable groundwater management, including "significant and unreasonable land subsidence that substantially interferes with surface land uses" (California Government, 2014). The U.S. Geological Survey (USGS), in cooperation with PV Water, analyzed land-surface deformation (subsidence and uplift) during 2015-18 that will aid in developing sustainable groundwater management criteria and can be used in future hydrologic models to help satisfy PV Water's Basin Management Plan and the SGMA.

\section{Purpose and Scope}

The purpose of this report is to present an assessment of land-surface deformation (subsidence and uplift) caused by aquifer-system deformation in parts of Pajaro Valley from 2015 through 2018. The relations of geology and groundwater altitudes to land-surface deformation is analyzed to better understand the hydromechanical response of the aquifer system under varied hydrologic conditions (above and below average rainfall and changes in groundwater management practices). Groundwater-altitude and land-surface deformation data are presented in a historical context to assess the potential for recoverable or permanent land-surface deformation.

\section{Description of Study Area}

Pajaro Valley is a coastal region primarily located in parts of Santa Cruz and Monterey Counties, in central California. The study area is the 124 square mile $\left(\mathrm{mi}^{2}\right)$ PV Water service area and includes the city of Watsonville (fig. 1). Pajaro Valley is bounded on the west by Monterey Bay and the Pacific Ocean, on the east and north by the Santa Cruz Mountains and the San Andreas fault zone, and on the south by Elkhorn Slough. Land-surface elevations range from sea level to about 1,600 feet (ft) above sea level in the foothills of the Santa Cruz Mountains. The valley is drained by the Pajaro River and its tributaries into Monterey Bay (fig. 1). The climate of Pajaro Valley is temperate with mild summers and wet, cool winters (Hanson, 2003). Long-term (1941-2018) rainfall averages about 21 inches per year (in/yr). During the study period (2015-18), precipitation ranged from a low of about 15 inches (in.) during 2018 to a high of about 40 in. during 2017 (California Department of Water Resources, 2021a).

\section{Geohydrologic Setting}

The Corralitos-Pajaro Valley groundwater basin (California Department of Water Resources, 2018; hereafter referred to as "Pajaro Valley") consists of multiple fluvial, alluvial-fan, and eolian sedimentary units, where fluctuations in sea level have controlled the sequence of depositional and erosional events. The basement rock consists of relatively low-permeability (consolidated) Cretaceous granitic rocks that are at depths of 2,000-4,000 ft along the coast (Johnson and others, 1988). Above the consolidated basement rock is a series of three westward-dipping, poorly consolidated to unconsolidated late Tertiary and Quaternary sediments that make up the aquifer system of Pajaro Valley: the Purisima Formation, the Aromas Red Sand, and the shallow alluvial/ lacustrine sediments. The Purisima Formation (Miocene and Pliocene) mostly consists of poorly consolidated marine sands, silts, and clays and underlays the study area from the land surface (in some areas) to depths of more than 2,000 ft below the land surface east of the Zayante-Vergeles fault zone (Greene, 1970; Johnson and others, 1988; Hanson and others, 2014). The Purisima Formation is overlain by the mostly unconsolidated Aromas Red Sand (Pleistocene) and consists of unconsolidated eolian and fluvial sand, silt, clay, and gravel.

The Aromas Red Sand is considered the primary water-bearing unit for Pajaro Valley and has been described as containing three subunits: the upper Aromas, a fine-grained confining unit, and the lower Aromas (Hanson and others, 2014). The upper Aromas subunit consists of terrestrial sedimentary deposits and ranges in thickness from 15 to $500 \mathrm{ft}$. The fine-grained confining subunit consists of marine sediments and ranges in thickness from 15 to $115 \mathrm{ft}$. The lower Aromas subunit consists of marine and fluvial sediments and ranges in thickness from 15 to $1,000 \mathrm{ft}$. The Aromas Red Sand is overlain by upward-fining sequences of unconsolidated alluvial fan, beach, and tidal-flat sediments that range in thickness from 15 to $380 \mathrm{ft}$ and lacustrine and marine fine-grained sediments that range in thickness from 15 to $500 \mathrm{ft}$. (Greene, 1970; Hanson and others, 2014). More detailed descriptions of the geologic and hydrologic setting of Pajaro Valley can be found in Wahrhaftig and Birman (1965), Dupre (1975, 1990), Tinsley (1975), Johnson and others (1988), and Hanson and others (2014).

There are three main fault zones within Pajaro Valley: The San Andreas, Zayante-Vergeles, and the Corralitos (Dupre, 1975). The San Andreas and Zayante-Vergeles fault zones are right-lateral, strike-slip faults that trend northwest; the San Andreas fault zone follows the foothills of the Santa Cruz Mountains, and the Zayante-Vergeles fault zone runs parallel to the San Andreas fault zone about 3 miles to the west (fig. 1). Both faults are at least partial barriers to groundwater flow (Hanson, 2003). The Corralitos fault zone is a convergent compressional wrench that sits between the San Andreas and Zayante-Vergeles fault zones (fig. 1); however, it is unknown if the Corralitos fault zone is a barrier to groundwater flow (Hanson, 2003). 


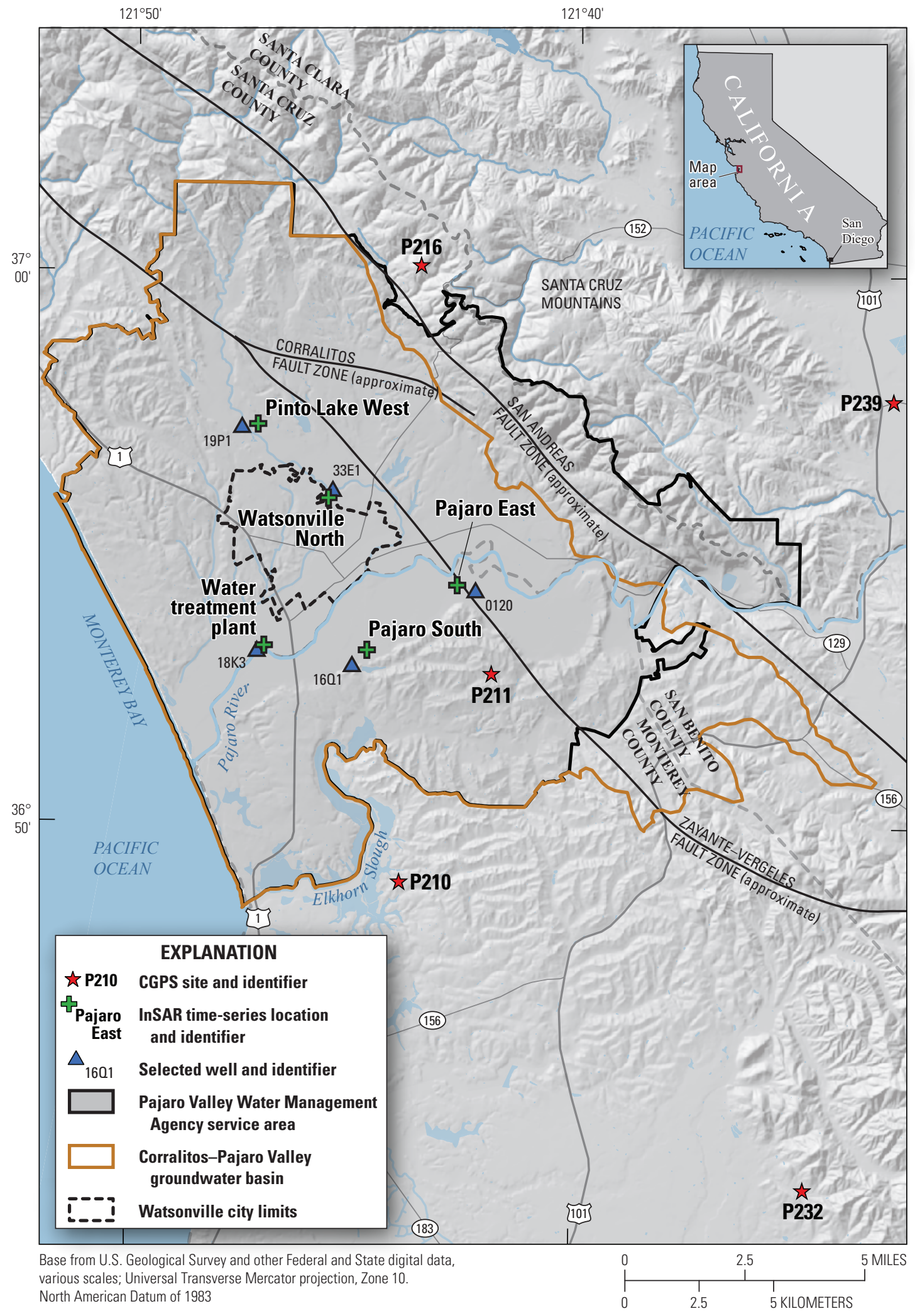

Figure 1. Study area showing selected continuous Global Positioning System (CGPS) sites, Interferometric Synthetic Aperture Radar (InSAR) time-series locations, wells, and other features, Pajaro Valley, California. Fault zones were modified from Dupre (1975) and Hanson (2003), and the groundwater basin boundary was defined in Bulletin 118 (California Department of Water Resources, 2018). 


\section{Mechanics of Pumping-Induced Land Subsidence}

Unconsolidated, sedimentary aquifer systems are supported by the grain structure of the sediments and the pore-fluid pressure of the groundwater that fills the spaces between the grains (fig. 2). Declines in groundwater altitudes reduce the pore-fluid pressure, increase the effective stress on the grain structure, and results in compaction of the aquifer system. Conversely, when groundwater altitudes increase, the pore-fluid pressure is increased, causing the grain structure of the aquifer system to expand (fig. 2).

Compaction of the grain structure of an aquifer system can be recoverable (elastic); however, if fine-grained sediments are present, any compressional deformation can be permanent (inelastic). Aquifer-system compaction can be elastic if the effective stress imposed on the aquifer system is less than any previous maximum effective stress (preconsolidation-stress threshold), which is sometimes the result of the lowest groundwater altitude (Leake and Prudic, 1991). When the preconsolidation stress threshold is exceeded, the grain structure of the aquifer system is permanently deformed from inelastic compaction (fig. 2). In aquifer systems with thick layers of fine-grained sediments, a substantial part of the total compaction lags effective stress, and this residual compaction can take decades or centuries to complete (Ireland and others, 1984). For more detailed descriptions of aquifer-system compaction, see Riley (1969), Holzer (1981), Poland (1984), Galloway and others (1999), and Sneed and Brandt (2020).

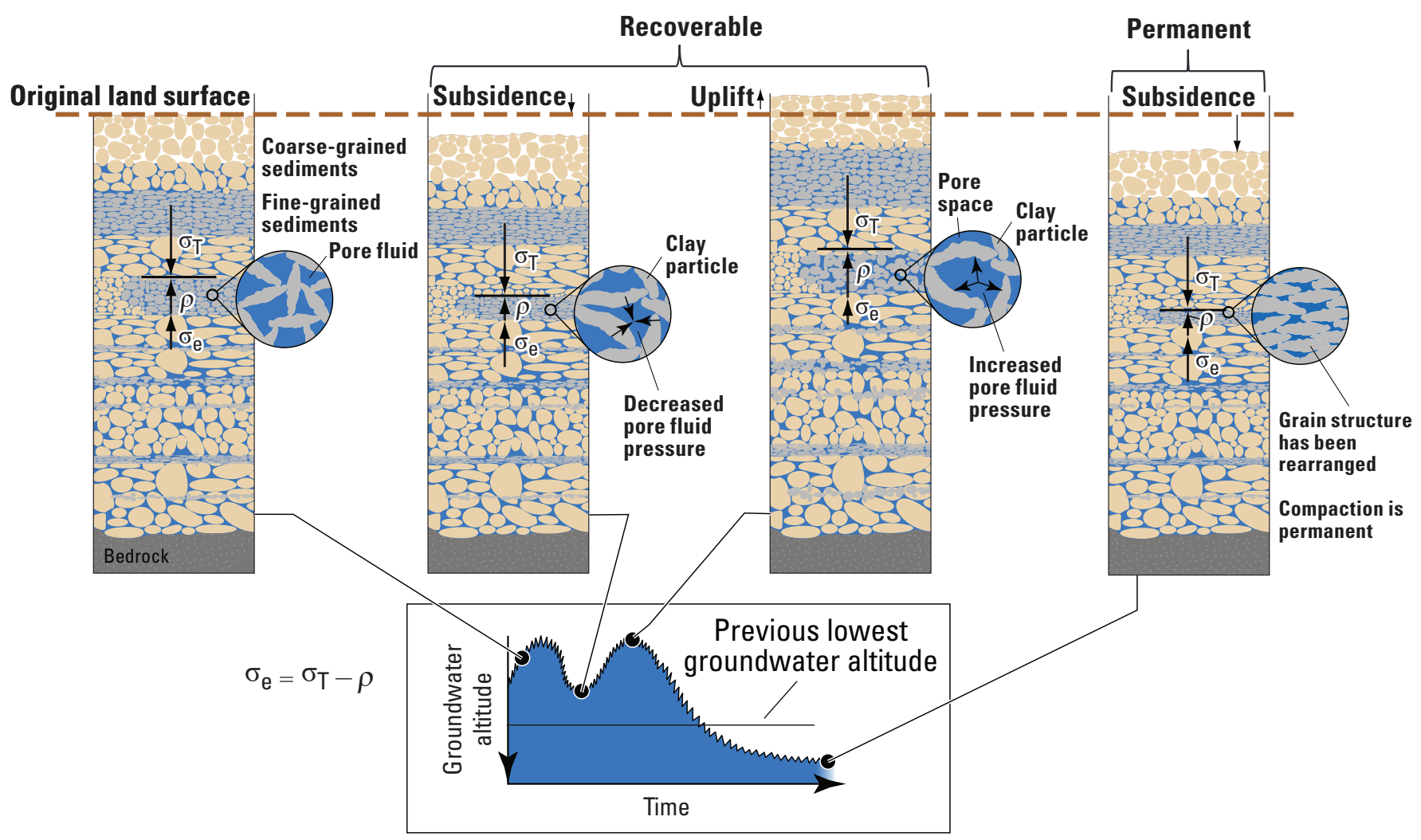

Figure 2. A simplified illustration of the principle of effective stress as applied to recoverable and permanent compaction of an aquifer system. In fine-grained sediments under conditions of constant total stress $\left(\sigma_{T}\right)$, decreased pore-fluid pressure $(\rho)$ results in increased effective stress $\left(\sigma_{e}\right)$ and deformation (compaction) of the grain structure in an aquifer system (modified from Galloway and others, 1999; Sneed and others, 2018). 


\section{Interferometric Synthetic Aperture Radar (InSAR)}

Interferometric Synthetic Aperture Radar (InSAR) is an effective way to measure land-surface deformation over large areas. InSAR is a satellite-based remote sensing technique that can detect land-surface deformation on the order of about one-half of an inch over thousands of square miles with spatial resolution (pixel size) on the order of about $300 \mathrm{ft}$ or less (Bawden and others, 2003).

Synthetic Aperture Radar (SAR) imagery is produced by reflecting radar signals off a target area and measuring the two-way travel time back to the satellite. As described in Sneed and others (2018), SAR imagery has two components: amplitude and phase. The amplitude is the radar signal intensity returned to the satellite and indicates the relative radar reflectivity of the landscape; phase is proportional to the line-of-sight distance from the ground to the satellite (range) and is used to measure land-surface deformation. The InSAR method (commonly referred to as conventional InSAR) used for this study uses two SAR images of the same area acquired at different times and "interferes" (differences) the phase portion of the SAR signal, resulting in spatially detailed maps called interferograms that show line-of-sight range change between the two satellite passes. The line-of-sight range change values are then converted to vertical deformation values using the look angle of the satellite to the target area. After multiple interferograms are generated for a target area, land-surface deformation time series can be extracted for most locations within the extent of each interferogram for further analysis.

The principal sources of error in the InSAR method applied to Pajaro Valley are atmospheric artifacts and agricultural land-use practices. Atmospheric water vapor (clouds or fog) slows the radar signal, causing a phase shift that can lead to erroneous deformation interpretations (Zebker and others, 1997). Phase shifts caused by atmospheric water vapor can often be corrected by combining two interferograms that share a common SAR image. For example, two interferograms $(\mathrm{AB}$ and $\mathrm{BC})$ are generated from three $\mathrm{SAR}$ images (A, B, and C). If a cloud is suspected in SAR image B, the apparent deformation measured using interferogram $A B$ will appear as subsidence (increased phase), and the apparent deformation measured using interferogram $\mathrm{BC}$ will appear as uplift (decreased phase). When these two interferograms are combined into a composite image, the equal and opposite phase change from each image will be cancelled out, effectively removing the portion of phase change caused by the cloud. The tilling of farm fields can cause large and non-uniform phase changes to occur, generating areas of poor pixel correlation (shown as randomly colored pixels on an interferogram) that cannot be interpreted.

\section{Interferometric Synthetic Aperture Radar Methods}

For this study, analysis of interferograms with short time spans between satellite acquisitions (as short as 12 days) was effective at minimizing time-dependent decorrelation of the pixels (for example, wide-spread decorrelation from tilling farm fields) because there is less opportunity for non-uniform changes to occur during this short period. Even with spans as short as 12 days, data gaps due to poor pixel correlation were still common in nearly all interferograms used for analysis. For a more detailed description of InSAR methods and error sources, see Sneed and others (2018) and Sneed and Brandt (2020).

SAR data from the European Space Agency's (ESA) Sentinel-1A satellite were acquired from the Alaska SAR Facility (https://asf.alaska.edu/) and used to generate interferograms for Pajaro Valley during 2015-18. Of the more than 300 interferograms processed for this study, qualitative and quantitative assessments resulted in the selection of 35 interferograms for further analysis (table 1; Brandt, 2021). Additional InSAR data from the California Department of Water Resources (2021b) were analyzed and compared to InSAR results from this study.

\section{Interferogram Quality Assessment}

The interferograms used in this report were assessed qualitatively and quantitatively. The qualitative assessment focused on identifying non-persistent deformation signals, which were attributed to artifacts (such as those caused by variable atmospheric moisture) or surficial activities (such as farming) that are unrelated to aquifer-system compaction. The quantitative assessment compared data extracted from interferograms for 2015-18 to continuous Global Positioning System (CGPS) data provided by the Scripps Orbit and Permanent Array Center (2019). Daily CGPS time-series data were downloaded for five CGPS sites distributed in and near the study area (figs. 1, 3). Continuous Global Positioning System can be used, in part, to differentiate between tectonic deformation and anthropogenic deformation, and because the CGPS data are available most days, direct comparisons generally can be made between InSAR and CGPS measurements. Because the selected CGPS sites generally are not in areas expected to be susceptible to aquifer-system compaction (typically installed in or near the foothills next to the valley), or are outside the study area, the CGPS data were used to assess the quality of individual interferograms and were not used to assess land-surface deformation related to groundwater pumping. 
Table 1. Interferometric Synthetic Aperture Radar (InSAR) interferograms interpreted for Pajaro Valley, California, 2015-18.

[InSAR data available in Brandt (2021). Index number is a unique identifier assigned to each interferogram. *Denotes interferogram with suspected phase delays from clouds or fog, which were mitigated using compositing techniques. Abbreviations: SAR, Synthetic aperture radar; $\mathrm{mm} / \mathrm{dd} /$ yyyy, month/day/year]

\begin{tabular}{|c|c|c|c|}
\hline $\begin{array}{c}\text { Index } \\
\text { number }\end{array}$ & $\begin{array}{c}\text { First SAR } \\
\text { acquisition } \\
\text { (mm/dd/yyyy) }\end{array}$ & $\begin{array}{l}\text { Second SAR } \\
\text { acquisition } \\
\text { (mm/dd/yyyy) }\end{array}$ & $\begin{array}{c}\text { Time span of } \\
\text { SAR pair, in } \\
\text { days }\end{array}$ \\
\hline 1 & 03/01/2015 & $04 / 18 / 2015$ & 48 \\
\hline 2 & $04 / 18 / 2015$ & $05 / 24 / 2015$ & 36 \\
\hline 3 & $05 / 24 / 2015$ & $07 / 23 / 2015$ & 60 \\
\hline 4 & $07 / 23 / 2015$ & $08 / 28 / 2015$ & 36 \\
\hline 5 & $08 / 28 / 2015$ & $10 / 27 / 2015$ & 60 \\
\hline $6^{*}$ & $10 / 27 / 2015$ & $11 / 20 / 2015$ & 24 \\
\hline $7 *$ & $11 / 20 / 2015$ & $12 / 02 / 2015$ & 12 \\
\hline 8 & $12 / 02 / 2015$ & $12 / 14 / 2015$ & 12 \\
\hline 9 & $12 / 14 / 2015$ & $12 / 26 / 2015$ & 12 \\
\hline $10 *$ & $12 / 26 / 2015$ & $02 / 12 / 2016$ & 48 \\
\hline $11 *$ & $02 / 12 / 2016$ & 03/19/2016 & 36 \\
\hline 12 & 03/19/2016 & $04 / 12 / 2016$ & 24 \\
\hline 13 & $04 / 12 / 2016$ & $05 / 06 / 2016$ & 24 \\
\hline $14^{*}$ & $05 / 06 / 2016$ & 05/18/2016 & 12 \\
\hline $15^{*}$ & $05 / 18 / 2016$ & 06/11/2016 & 24 \\
\hline 16 & $06 / 11 / 2016$ & $07 / 05 / 2016$ & 24 \\
\hline 17 & 07/05/2016 & 07/29/2016 & 24 \\
\hline $18^{*}$ & 07/29/2016 & $08 / 22 / 2016$ & 24 \\
\hline $19^{*}$ & $08 / 22 / 2016$ & $09 / 15 / 2016$ & 24 \\
\hline 20 & $09 / 15 / 2016$ & $10 / 21 / 2016$ & 36 \\
\hline 21 & $10 / 21 / 2016$ & $12 / 20 / 2016$ & 60 \\
\hline 22 & $01 / 25 / 2017$ & 03/02/2017 & 36 \\
\hline 23 & 03/02/2017 & 03/26/2017 & 24 \\
\hline 24 & 03/26/2017 & 04/19/2017 & 24 \\
\hline $25 *$ & 04/19/2017 & $05 / 13 / 2017$ & 24 \\
\hline $26^{*}$ & 05/13/2017 & $06 / 18 / 2017$ & 36 \\
\hline 27 & $06 / 18 / 2017$ & 08/17/2017 & 60 \\
\hline 28 & 08/17/2017 & $10 / 16 / 2017$ & 60 \\
\hline $29^{*}$ & $10 / 16 / 2017$ & $12 / 15 / 2017$ & 60 \\
\hline $30 *$ & $12 / 15 / 2017$ & $01 / 20 / 2018$ & 36 \\
\hline 31 & $01 / 20 / 2018$ & $02 / 13 / 2018$ & 24 \\
\hline 32 & $02 / 13 / 2018$ & $04 / 14 / 2018$ & 60 \\
\hline 33 & $04 / 14 / 2018$ & 05/20/2018 & 36 \\
\hline 34 & $05 / 20 / 2018$ & $07 / 19 / 2018$ & 60 \\
\hline 35 & 07/19/2018 & 09/17/2018 & 60 \\
\hline
\end{tabular}

Day-to-day CGPS vertical deformation measurements varied by nearly $1.0 \mathrm{in}$., which is likely the result of variable atmospheric moisture, electronic noise, and other effects not directly related to land-surface-deformation (Zerbini and others, 2001; Williams and others, 2004; Langbein, 2008). To minimize this high-frequency noise and to enable better comparison between changes in CGPS and InSAR measurements, a 31-day moving average was applied to the CGPS data. This high frequency filter did not remove seasonal or long-term deformation trends and permitted more meaningful comparisons with InSAR results (fig. 3).

\section{Interferometric Synthetic Aperture Radar Results}

The qualitative and quantitative InSAR-data assessments resulted in the selection of 35 mostly time-sequential interferograms that spanned between 12 and 60 days (table 1). Collectively, the selected interferograms represent a nearly continuous period between March 2015 and September 2018, except for a single 36-day gap from December 20, 2016, to January 25, 2017, when suitable InSAR data were not available. Of these interferograms, 12 (6 pairs of time-sequential interferograms; each pair having a common SAR image) are suspected to contain phase delays from atmospheric vapor. As described in the "Interferometric Synthetic Aperture Radar Methods" section, a composite interferogram was generated from each pair of interferograms to remove the apparent deformation that was attributed to atmospheric conditions. It is assumed that deformation did not occur during data gaps caused by poor pixel correlation in individual interferograms, and the InSAR data gap from December 20, 2016, to January 25, 2017. Combining the 23 individual interferograms with the 6-composite atmospheric-corrected interferograms resulted in 29 interferograms during the 3.5-year study period. Of the 106 comparisons between InSAR and CGPS results, nearly 91 percent agreed within 0.5 in., with a root mean square error (RMSE) of about 0.3 in. This low RMSE value demonstrates that measurements of land-surface deformation using InSAR methods are reasonably accurate. 
$\boldsymbol{A}$

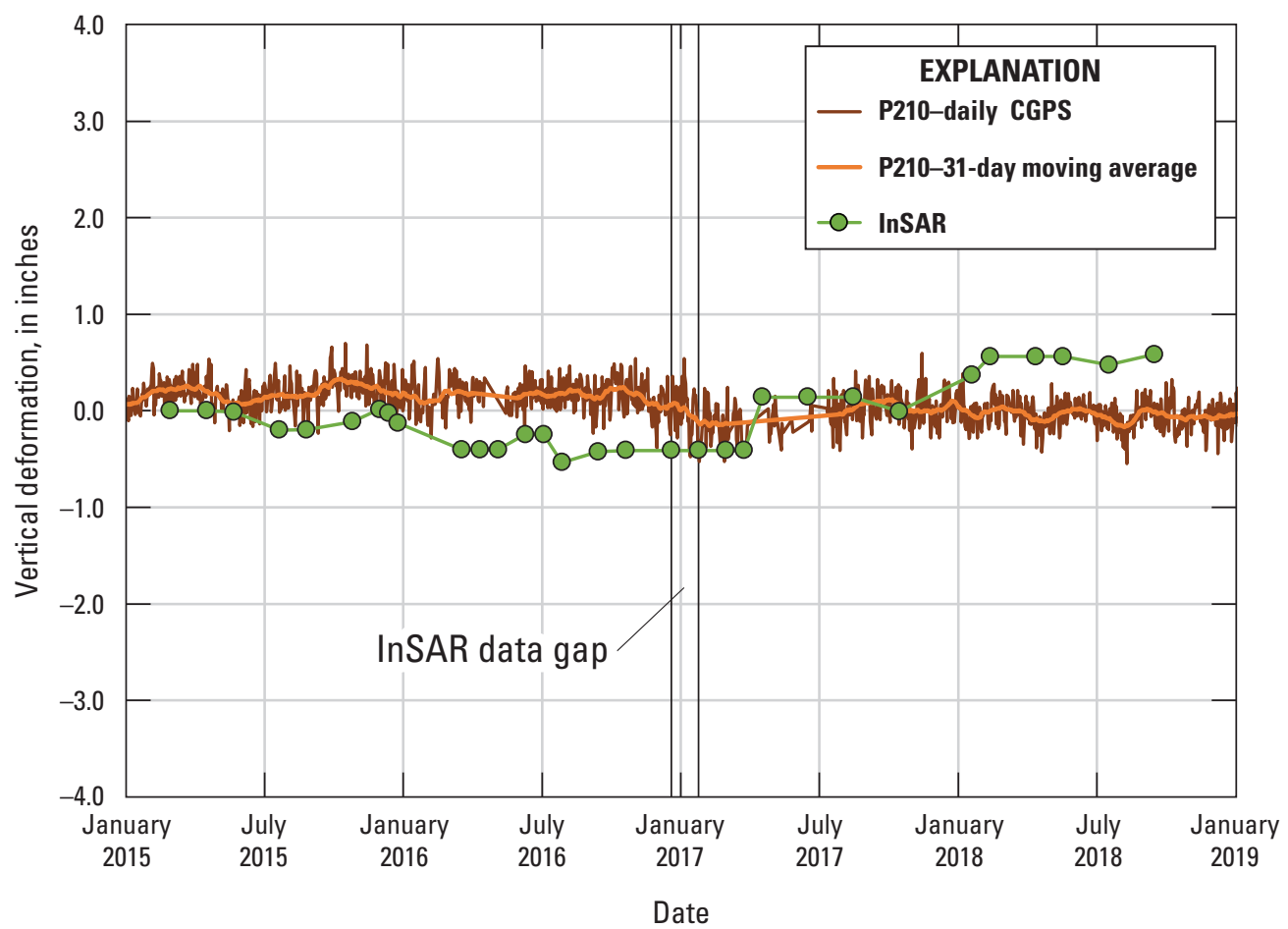

$B$

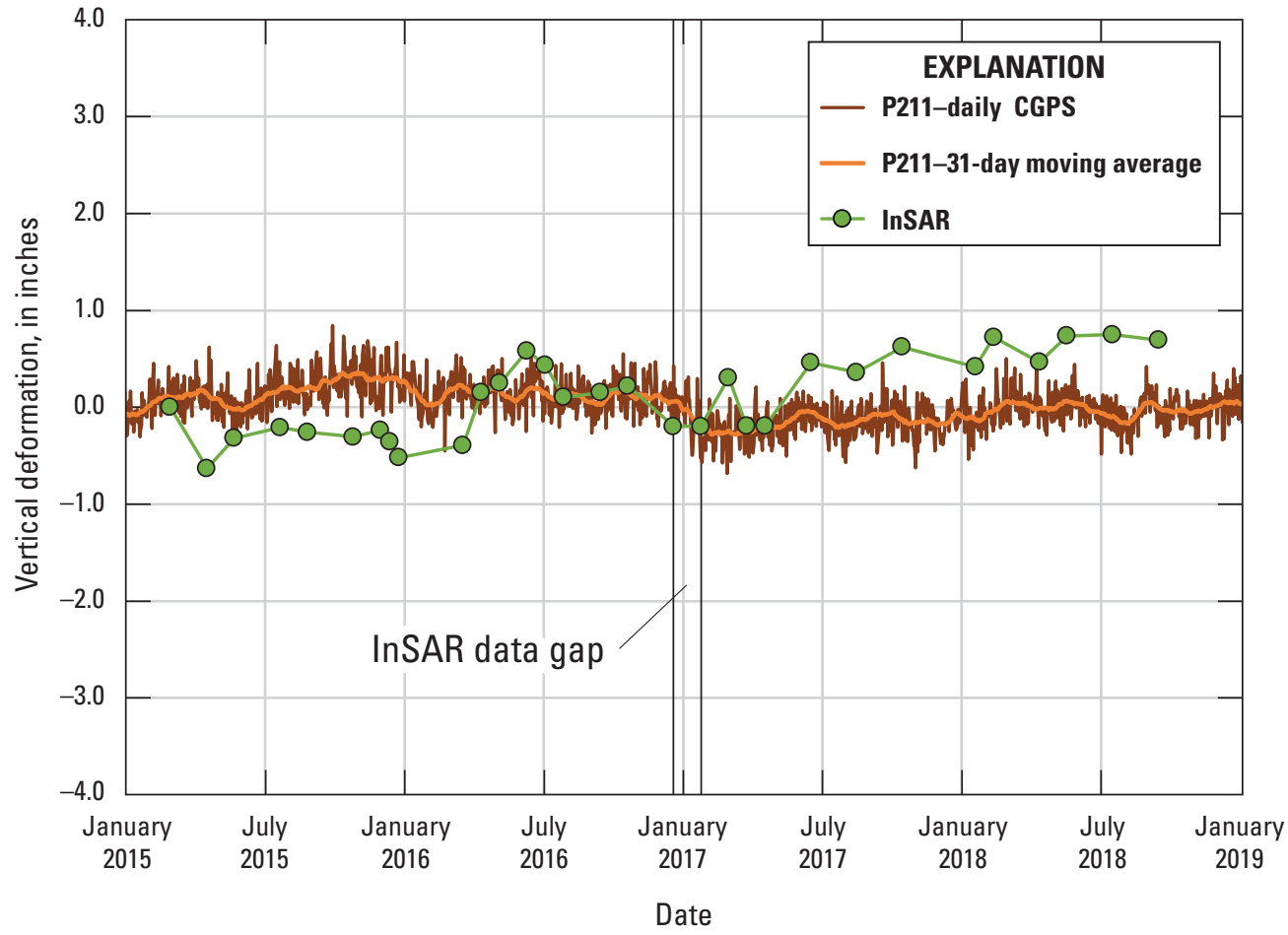

Figure 3. Vertical deformation measured by continuous Global Positioning System (CGPS) and by Interferometric Synthetic Aperture Radar (InSAR) at selected CGPS sites, in Pajaro Valley, California, 2015-18: A, P210; $B$, P211; C, P216; D, P232; and E, P239. See figure 1 for CGPS site locations. The CGPS data were provided by Scripps Orbit and Permanent Array Center (2019), and InSAR data are available in Brandt (2021). 
C

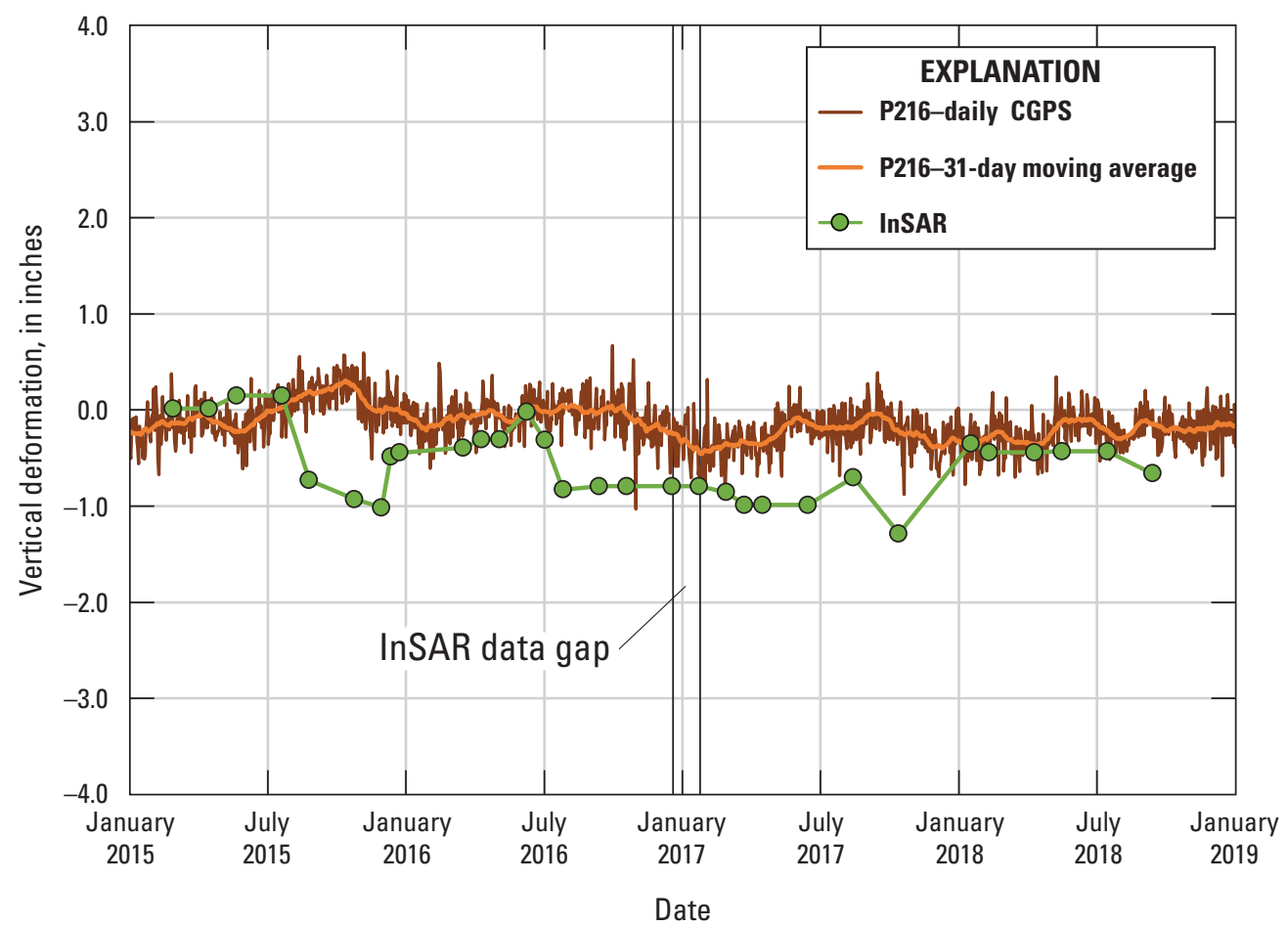

D

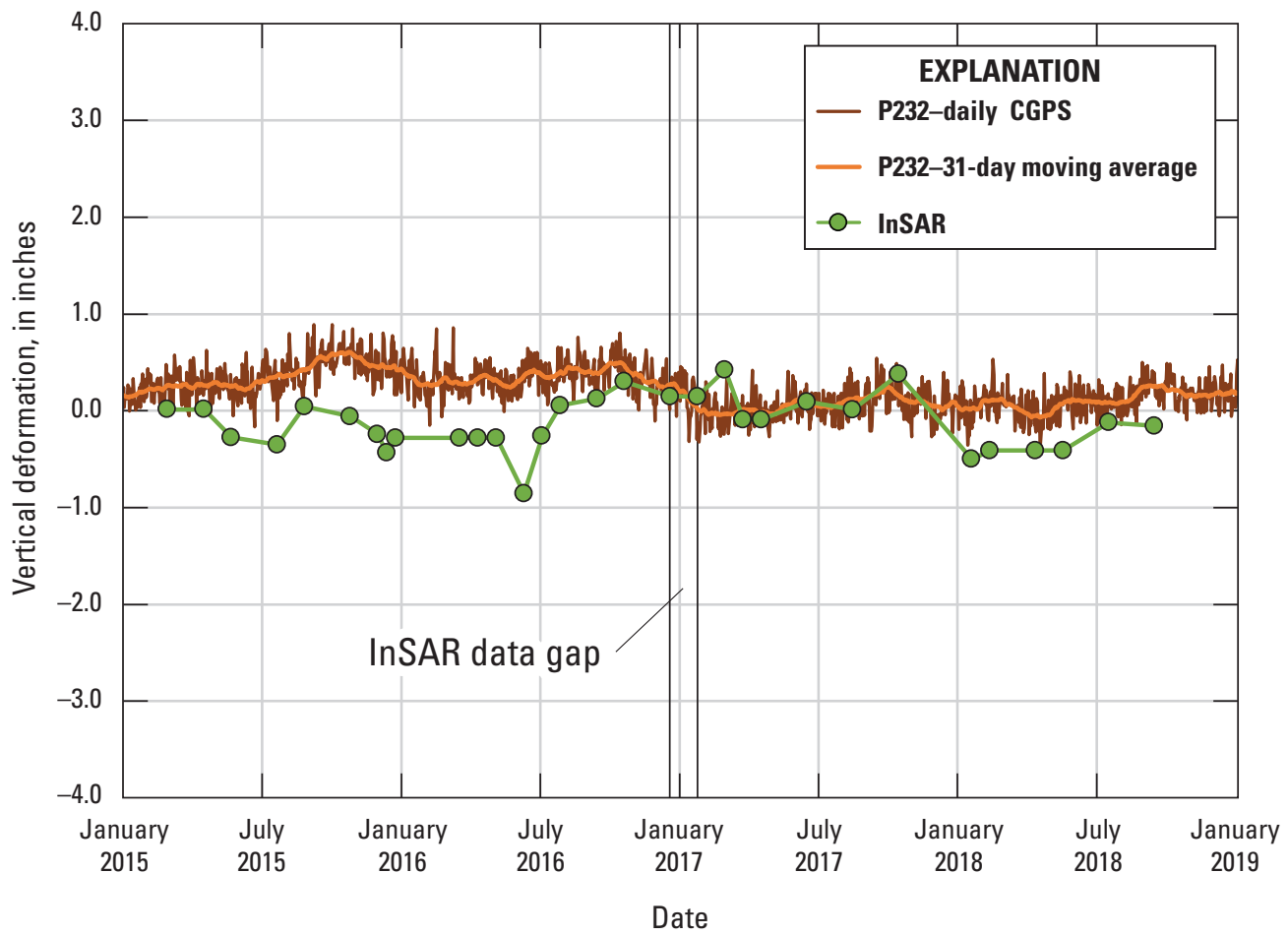

Figure 3.-Continued 


\section{$\boldsymbol{E}$}

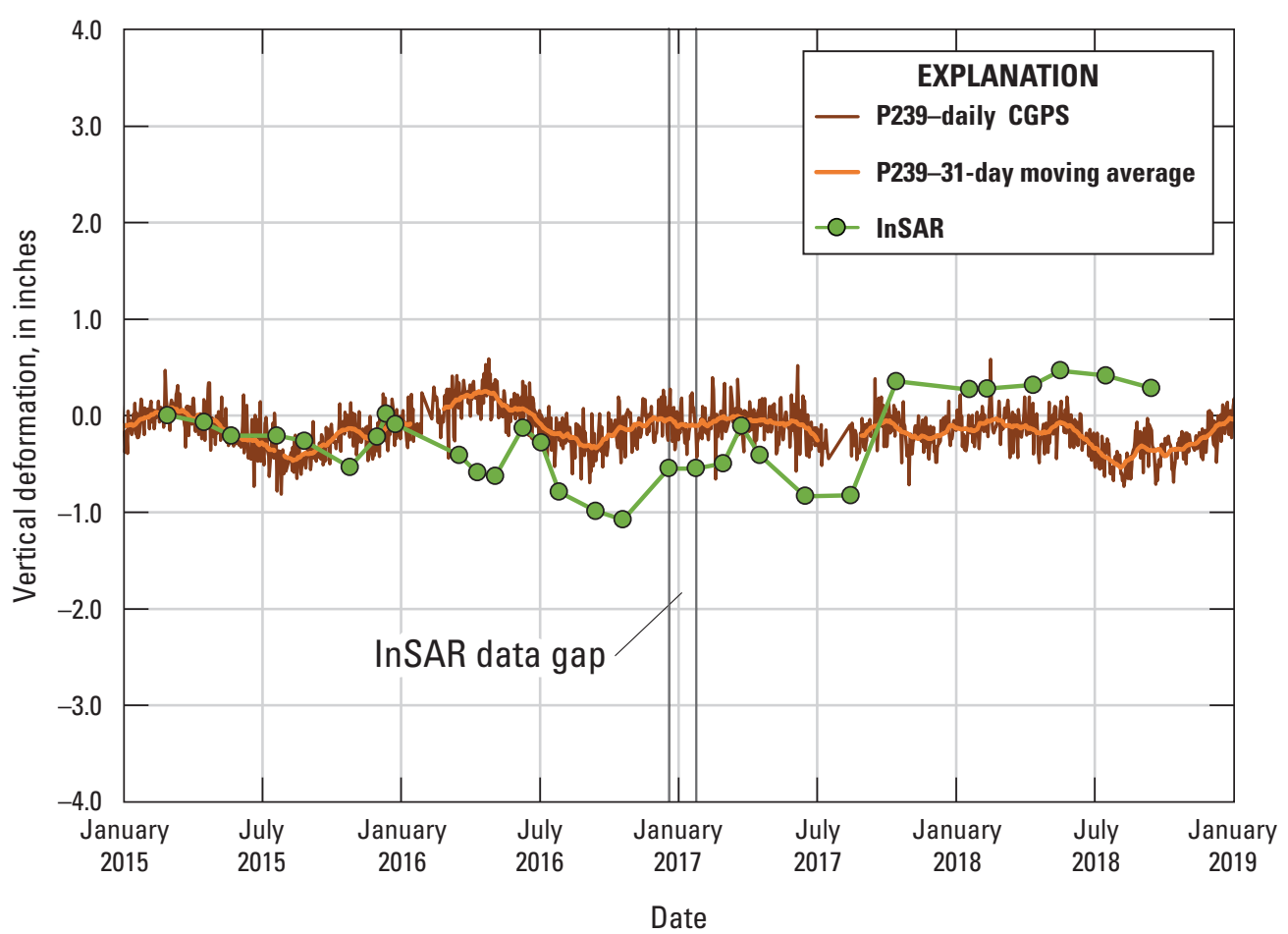

Figure 3.-Continued

The 29 interferograms (23 individual interferograms and 6 composite, atmospheric-corrected interferograms) were analyzed individually to construct time series at selected locations. The land-surface deformation measured at these locations was generally representative of the rest of the study area where groundwater was expected to be withdrawn and indicated as much as about $1.0 \mathrm{in}$. of seasonal land-surface deformation superimposed on annual and multi-annual stability during 2015-18 (InSAR time series locations: Pinto Lake West, Pajaro East, Water treatment plant, and Pajaro South, figs. $4 A, 4 C, 4 D$, and $4 E$ ). The magnitudes of measured land-surface deformation for individual interferograms generally are comparable to expected error tolerances ( $0.5 \mathrm{in}$.). One area just north of the Watsonville city limits indicated slightly higher magnitudes of deformation, where about -1.5 in. of vertical deformation (subsidence) occurred during 2015-18 (Watsonville North; fig. 4B).
InSAR data available from the California Department of Water Resources' (CDWR) SGMA Data Viewer (California Department of Water Resources, 2021b) were analyzed for this study. The CDWR data utilized the same Sentinel-1A satellite as this study and are available for a comparable period (June 2015 through September 2018), but the CDWR data utilized entirely different processing methods. The CDWR data indicated that land-surface deformation in the study area was less than 0.5 in. during June 2015-September 2018 (California Department of Water Resources, 2021b). Although the CDWR data were not as spatially or temporally detailed as the InSAR data presented in this report (Brandt, 2021), both datasets indicated multi-annual stability for the study area within expected error tolerances ( 0.5 in., as described earlier in this report). 
A

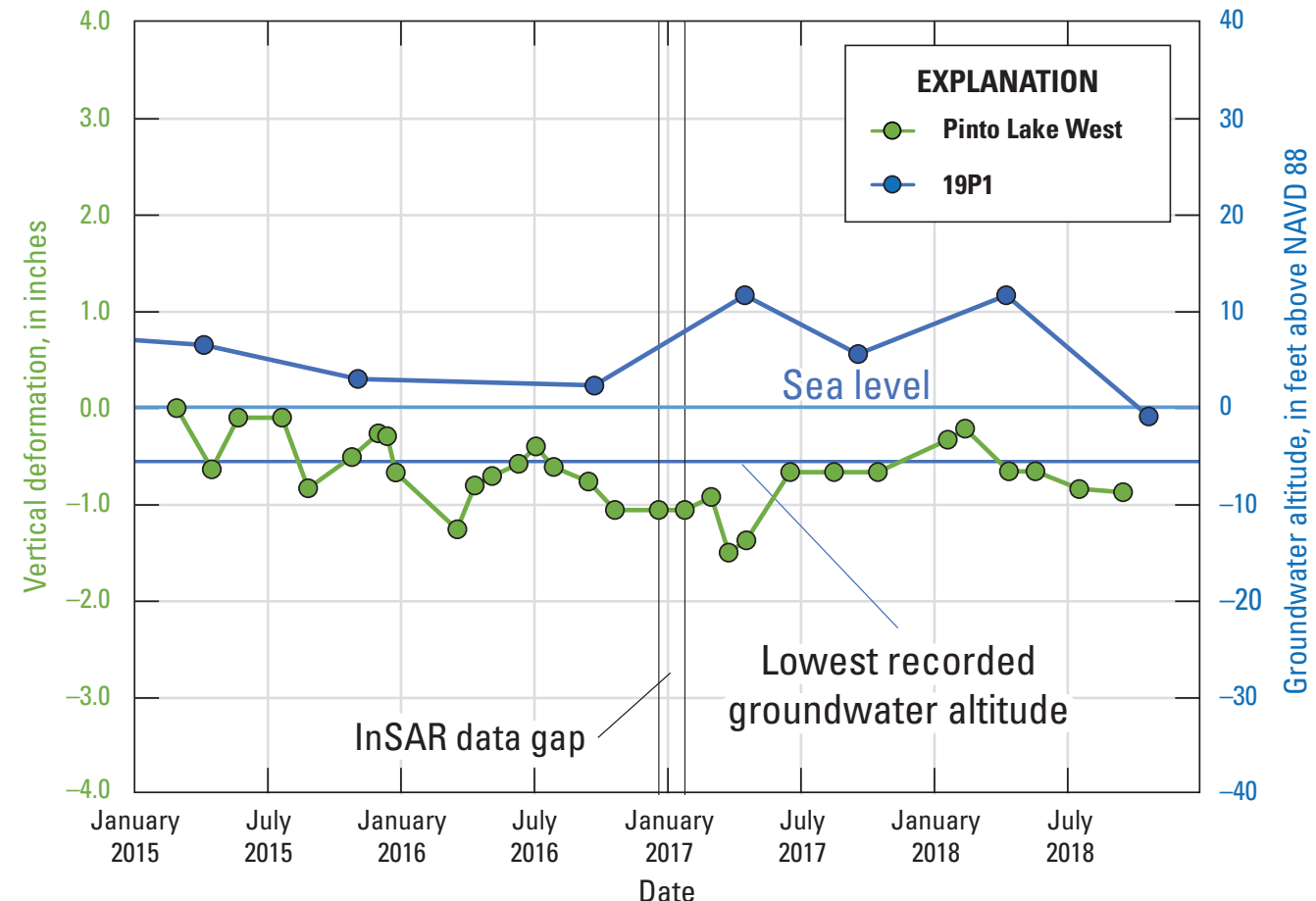

B

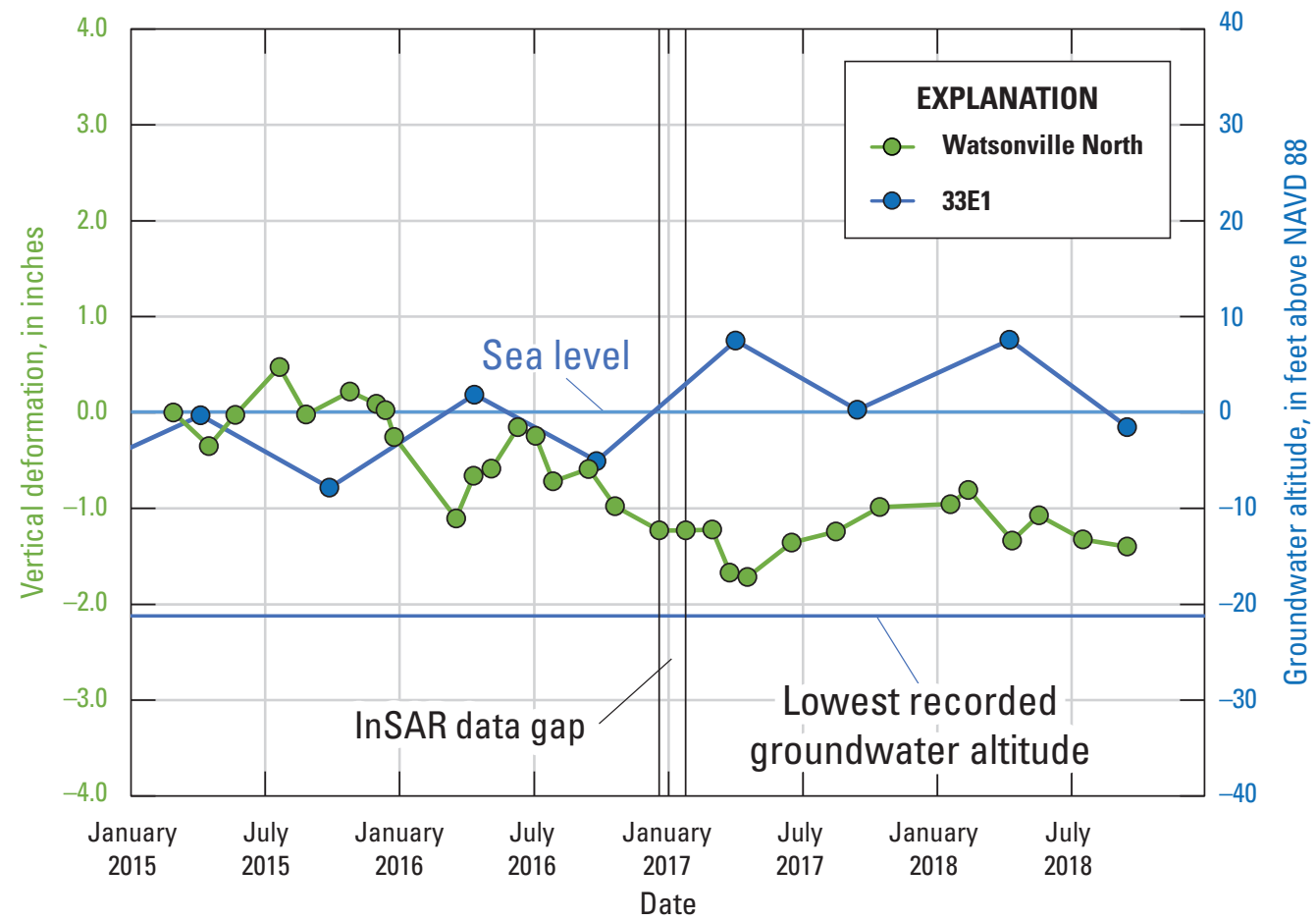

Figure 4. Interferometric Synthetic Aperture Radar (InSAR) time series and groundwater altitudes in Pajaro Valley, California, 2015-18: A, Pinto Lake West and well 19P1 (perforated in the upper Aromas Sand to the Purisima Formation); $B$, Watsonville North and well 33E1 (perforated in the upper Aromas Sand); $C$, Pajaro East and well 0120 (perforated in the upper Aromas Sand); D, Water treatment plant and well 18K3 (perforated in the shallow alluvium and within the cone of depression in groundwater altitudes described in Hanson and others [2014]); and E, Pajaro South and well 1601 (perforated in the lower Aromas Sand). Groundwater-altitude data were provided by the Pajaro Valley Water Management Agency and are available in Brandt (2021). See figure 1 for InSAR time series and well locations. 
C

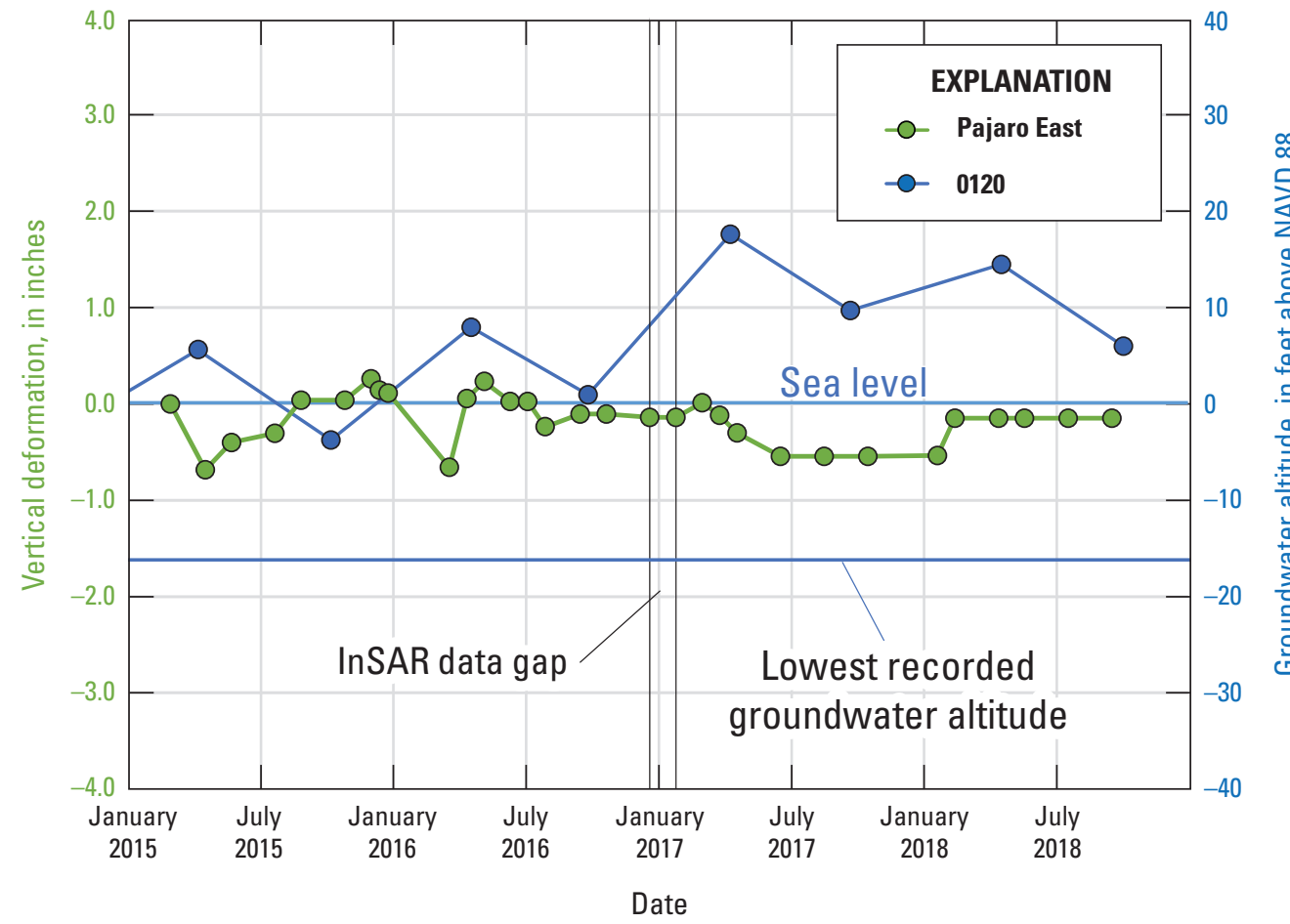

D

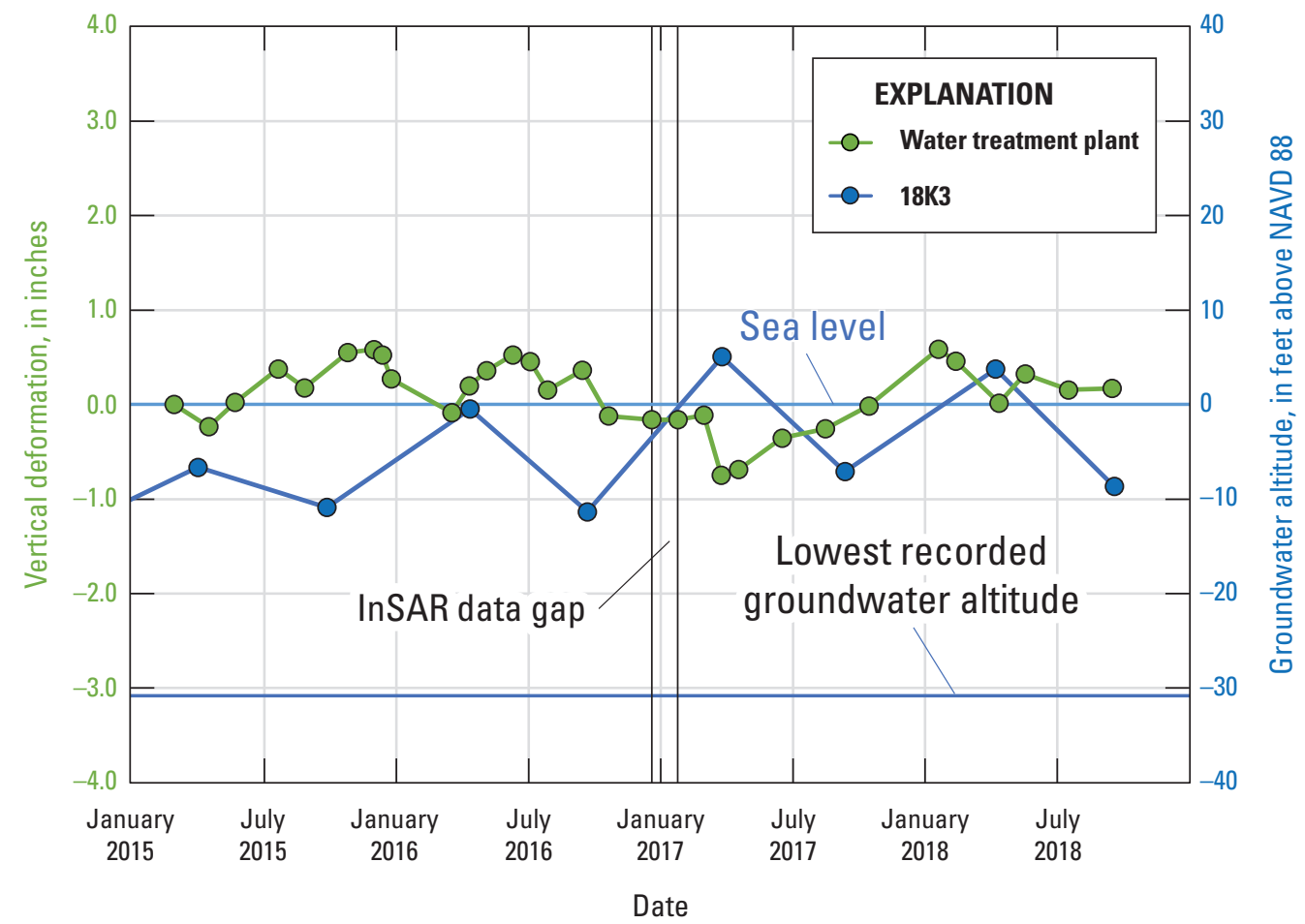

Figure 4.-Continued 


\section{$\boldsymbol{E}$}

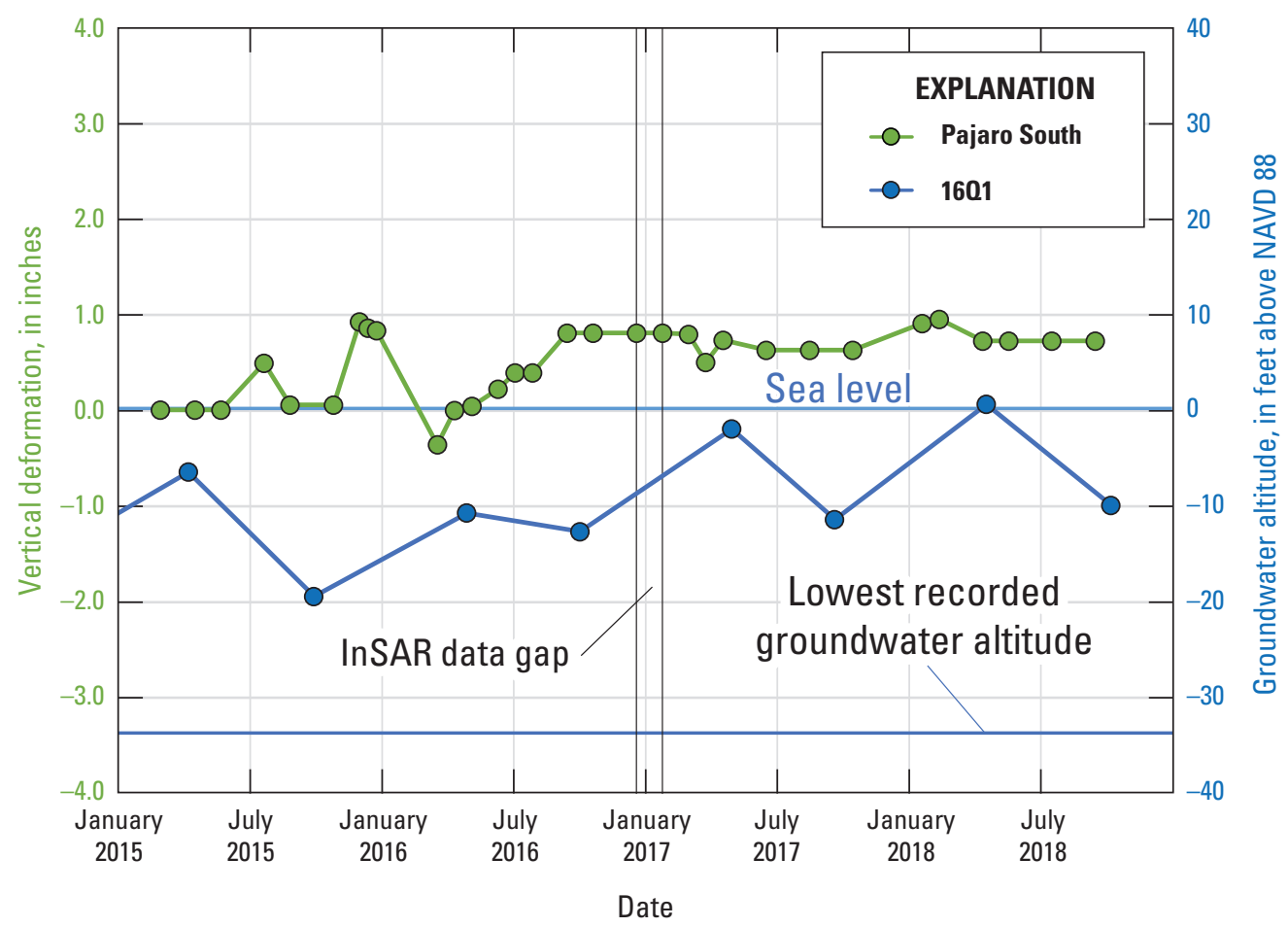

Figure 4.-Continued

\section{Groundwater Altitudes}

Groundwater-altitude changes in Pajaro Valley are related to several factors, including climatic and seasonal cycles that effect recharge, agricultural pumpage (increased demand during the May through October growing season), and PV Water's conservation efforts, (Pajaro Valley Water Management Agency, 2019).

Groundwater-altitude data available in Brandt (2021) generally indicated seasonal variability and longer term (annual to multi-annual) increases during 2015-18 (figs. 4A-E). Groundwater altitudes were up to about $10 \mathrm{ft}$ lower during summer/early fall compared to the previous winter/spring (for example, well 0120, fig. 4C). Superimposed on this seasonal variation were increases of about $5 \mathrm{ft}$ per year during subsequent summer/early fall months for 2015 through 2017 (for example, well 33E1, fig. 4B). The next year (2018), many groundwater altitudes during summer/ early fall decreased by more than $5 \mathrm{ft}$ relative to the prior summer/early fall (for example, well 19P1, fig. 4A). This change of increasing groundwater altitudes during 2015-17 to decreasing groundwater altitudes during 2017-18 coincides with a change in precipitation in the valley. In 2017, parts of Pajaro Valley received about 40 in. of precipitation or about double the long-term average, and in 2018, parts of Pajaro Valley received only about 15 in. of precipitation or about three-quarters the long-term average (California Department of Water Resources, 2021a; fig. 5). The reduced precipitation in 2018 increased demand on groundwater resources, resulting in decreased groundwater altitudes relative to the prior year (Pajaro Valley Water Management Agency, 2019; figs. 4, 5).

Groundwater altitudes throughout Pajaro Valley generally declined below sea level during drought periods in 1947 , 1976-77, 1987-92, 2007-09, and 2012-16. Following the 1947 drought, groundwater altitudes monitored by PV Water increased above sea level within 4 years (Pajaro Valley Water Management Agency, 2014). Following the 1976-77 drought, some groundwater altitudes increased above sea level by the early 1980 s only to fall below sea level shortly after (for example, well 16Q1, fig. 5). Following the 1987-92 drought, groundwater altitudes had not increased above sea level for much of the study area by 1998, even after more than 4 years of above average precipitation (Pajaro Valley Water Management Agency, 2014; fig. 5). Collectively, these decreased groundwater altitudes created a cone of depression that encompassed the city of Watsonville (Hanson and others, 2014). Generally, groundwater altitudes presented in this report during 2015-18 (which includes the later portion of the 2012-16 drought) were 15 or more $\mathrm{ft}$ higher than their lowest recorded altitudes set during or soon after the 1987-92 drought period. Efforts by PV Water to mitigate groundwater altitudes that previously declined below sea level likely contributed to the observed longer-term (decadal) groundwater-altitude increases, even during the later portions of the 2012-16 drought (fig. 5). However, groundwater altitudes in many of these wells still were below sea level for at least part of 2015-18. 


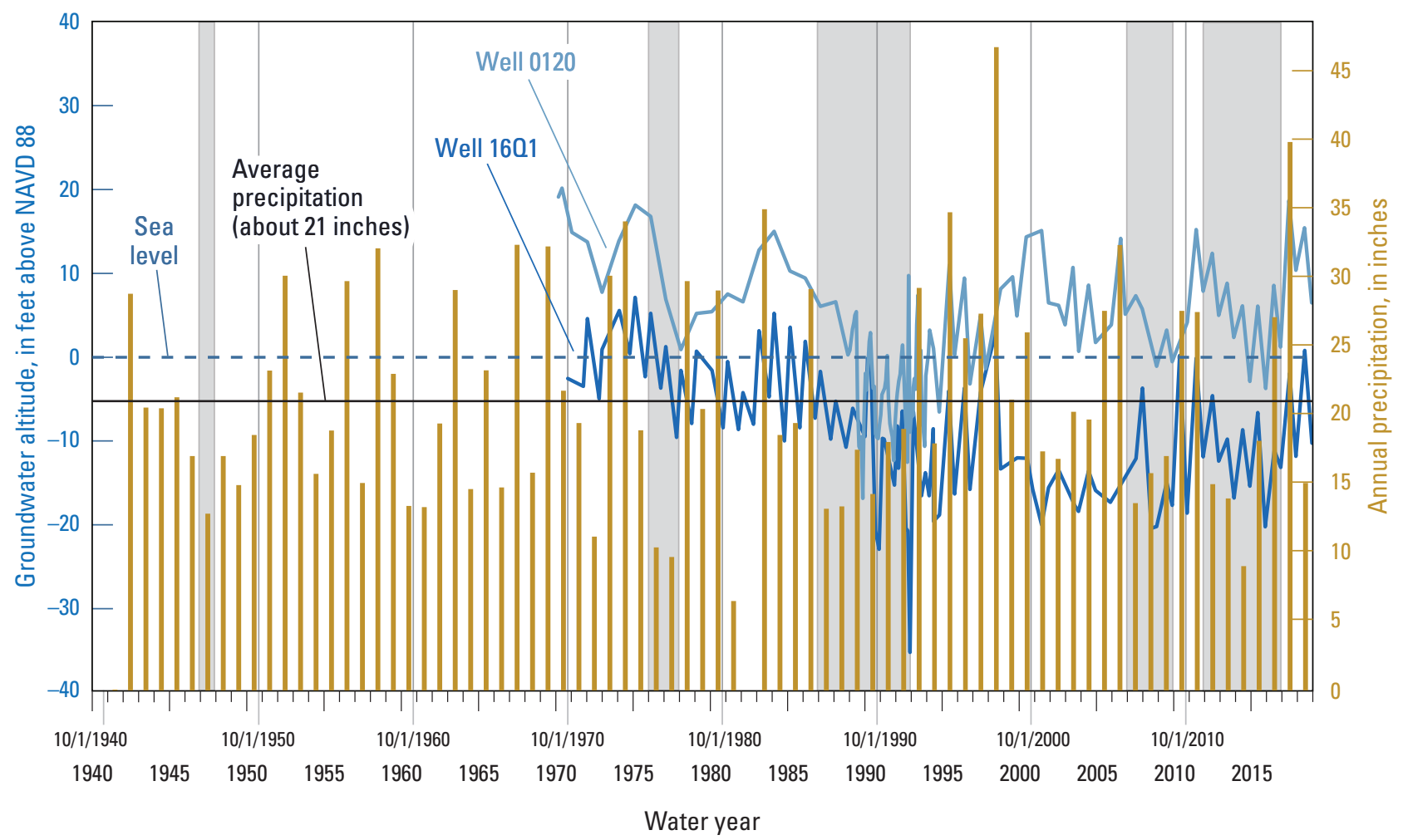

Figure 5. Precipitation and selected groundwater-altitude data in Pajaro Valley, California, water years 1941-2018. Gray boxes indicate drought periods as described by California Department of Water Resources (2021c). Precipitation data were from California Department of Water Resources (2021a), and groundwater-altitude data were provided by the Pajaro Valley Water Management Agency and are available in Brandt (2021).

\section{Relation of Geology and Groundwater Altitudes to Land-Surface Deformation}

The relation between geology (particularly lithology) and groundwater altitudes to land-surface deformation indicates the hydromechanical response of an aquifer system under varied hydrologic conditions. In Pajaro Valley, unconsolidated fine-grained (clay) sediments and confining units are present, and groundwater altitudes have fluctuated because of varied hydrologic conditions (climate variability and changes in groundwater management). The unconsolidated and fine-grained sediments in Pajaro Valley were expected to be susceptible to aquifer-system compaction due to decreased groundwater altitudes as a result of groundwater development. However, groundwater altitudes presented in this report reached historical lows in the late 1980s or early 1990s and generally increased to present day (2018). These historically low groundwater altitudes were presumed to represent the preconsolidation stress threshold, and groundwater altitudes being maintained above their historical lows decrease the potential for permanent land subsidence. Groundwater-altitude increases in wells, coupled with small deformation magnitudes (less than about 2 inches), indicate that any land-surface deformation during 2015-18 likely was predominantly recoverable. 


\section{Summary and Conclusions}

The U.S. Geological Survey, in cooperation with the Pajaro Valley Water Management Agency (PV Water), performed an analysis of land-surface deformation (subsidence and uplift) for 2015-18 in Pajaro Valley using remote sensing techniques that could, in part, aid in developing monitoring and land-subsidence threshold criteria for sustainable groundwater management. PV Water is developing groundwater sustainability criteria as part of their Basin Management Plan and to comply with California's Sustainable Groundwater Management Act requirements. Before this land-surface deformation study, PV Water and stakeholders had implemented a series of projects that aimed to offset groundwater pumping demand and decrease seawater intrusion in the coastal regions of PV Water's service area. Results of this study indicated these projects likely contributed to increased groundwater altitudes and a generally stable land surface during 2015-18 (which includes the later portion of the 2012-16 drought). The largest magnitude of land-surface deformation (less than 2 inches of subsidence) was localized to an area just north of the city limits of Watsonville, California, and likely was predominantly recoverable.

Although the land surface in Pajaro Valley largely was stable during 2015-18, the presence of fine-grained (clay) sediments indicated the potential for permanent aquifer-system compaction and resultant subsidence should future groundwater altitudes decline below historical lows. Continued monitoring of groundwater altitudes and land-surface deformation (uplift and subsidence) is informative because it enables researchers and stakeholders to discover small problems (for example, small magnitudes of recoverable compaction) before they become large problems (larger magnitudes of permanent compaction).

\section{References Cited}

Bawden, G.W., Sneed, M., Stork, S.V., and Galloway, D.L., 2003, Measuring human-induced land subsidence from space: U.S. Geological Survey Fact Sheet 069-03, 4 p., https://doi.org/10.3133/fs06903.

Brandt, J.T., 2021, Interferometric Synthetic Aperture Radar and Water Level Data, Pajaro Valley, Santa Cruz and Monterey Counties, California, 1970-2018, U.S. Geological Survey data release, https://doi.org/10.5066/P9FNARQO.

Brandt, J.T., Sneed, M., and Danskin, W.R., 2020, Detection and measurement of land subsidence and uplift using interferometric synthetic aperture radar, San Diego, California, USA, 2016-2018: Proceedings of the International Association of Hydrological Sciences, v. 382, p.45-49, https://doi.org/10.5194/piahs-382-45-2020.

California Department of Water Resources, 2018, ArcGIS REST Services directory, SMGA Data Viewer: California Department of Water Resources website, accessed June 4, 2021, at https://gis.water.ca.gov/arcgis/rest/services/ Geoscientific/i08_B118_CA_GroundwaterBasins/ FeatureServer.

California Department of Water Resources, 2021a, California Data Exchange Center website, accessed May 26, 2021, at http://cdec4gov.water.ca.gov/dynamicapp/selectQuery? Stations $=$ WTW $\&$ SensorNums $=2 \&$ dur_code $=$ M $\&$ Start $=$ 1939-10-01\&End=2020-09-31. 
California Department of Water Resources, 2021b, ArcGIS REST Services directory, SMGA Data Viewer: California Department of Water Resources website, accessed January 4, 2021, at https://gis.water.ca.gov/arcgisimg/rest/ services/SAR/Vertical_Displacement_TRE_ALTAMIRA v2019_Total_Since_20150613_20180901/ImageServer.

California Department of Water Resources, 2021c, Calfiornia Department of Water

Resources website, accessed August 17, 2021, at https:/water.ca.gov/Programs/All-Programs/Drought/.

California Government, 2014, California Sustainable Groundwater Management Act, water code section 10721: California Legislative Information website, accessed September 17, 2021, at https://leginfo.legislature.ca.gov/ faces/billTextClient.xhtml?bill_id=201320140AB1739.

Dupre, W.R., 1975, Quaternary history of the Watsonville lowlands north-central Monterey Bay region, California: Stanford University, Ph.D. dissertation, 145 p., accessed June 3, 2021, at https://searchworks.stanford.edu/view/879689.

Dupre, W.R., 1990, Maps showing geology and liquefaction susceptibility of Quaternary deposits the Monterey, Seaside, Spreckels, and Carmel Valley quadrangles, Monterey County, California: U.S. Geological Survey Miscellaneous Field Studies Map 2096, https://doi.org/10.3133/mf2096.

Galloway, D.L., Jones, D.R., and Ingebritsen, S.E., 1999, Land subsidence in the United States: U.S. Geological Survey Circular 1182, 177 p., https://doi.org/10.3133/cir1182.

Greene, H.G., 1970, Geology of southern Monterey Bay and its relationship to the ground water basin and salt-water intrusion: U.S. Geological Survey Open File report 1970-141, 51 p., https://doi.org/10.3133/ofr70141.

Hanson, R.T., 2003, Geohydrologic framework of recharge and seawater intrusion in the Pajaro Valley, Santa Cruz and Monterey Counties, California: U.S. Geological Survey Water-Resources Investigation Report 2003-4096, 88 p., https://doi.org/10.3133/wri034096.

Hanson, R.T., Martin, P., and Koczot, K.M., 2003, Simulation of ground-water/surface-water flow in the Santa Clara-Calleguas ground-water basin, Ventura County, California: U.S. Geological Survey Water-Resources Investigation Report 02-4136, 214 p., https://doi.org/10.3133/wri024136.

Hanson, R.T., Schmid, W., Faunt, C.C., Lear, J., and Lockwood, B., 2014, Integrated hydrologic model of Pajaro Valley, Santa Cruz and Monterey counties, California: U.S. Geological Survey Scientific Investigations Report 2014-5111, 166 p., https://doi.org/10.3133/sir20145111.
Holzer, T.L., 1981, Preconsolidation stress of aquifer systems in areas of induced land subsidence: Water Resources Research, v. 17, no. 3, p. 693-703, https://doi.org/10.1029/WR017i003p00693.

Ireland, R.L., Poland, J.F., and Riley, F.S., 1984, Land subsidence in the San Joaquin Valley, California, as of 1980: U.S. Geological Survey Professional Paper 437-I, 93 p., https://doi.org/10.3133/pp437I.

Johnson, M.J., Londquist, C.J., Laudon, J., and Mitten, H.T., 1988, Geohydrology and mathematical simulation of the Pajaro Valley aquifer system, Santa Cruz and Monterey Counties, California: U.S. Geological Survey Water-Resources Investigations Report 87-4281, 62 p., https://doi.org/10.3133/wri874281.

Langbein, J., 2008, Noise in GPS displacement measurements from Southern California and Southern Nevada: Journal of Geophysical Research, v. 113, no. B5, 12 p., https://doi.org/10.1029/2007JB005247.

Leake, S.A., and Prudic, D.E., 1991, Documentation of a computer program to simulate aquifer-system compaction using the modular finite-difference ground-water flow model: U.S. Geological Survey Techniques of Water-Resources Investigations, book 6, chap. A2, 68 p., https://doi.org/10.3133/twri06A2.

Pajaro Valley Water Management Agency, 2014, Basin management plan update: Pajaro Valley Water Management Agency, 220 p., accessed December 11, 2020, at https://www.pvwater.org/images/about-pvwma/assets/bmp update_eir_final_2014/BMP_Update_Final_February_ 2014_(screen).pdf.

Pajaro Valley Water Management Agency, 2019, Pajaro Valley subbasin-Water year 2018 annual report: Pajaro Valley Water Management Agency, 33 p., accessed December 8, 2020, at https://www.pvwater.org/images/about-pvwma/ assets/annual_reports_assets/SGMA-WY/SGMA_ WY2018_AR_Compiled_Final-web.pdf.

Pajaro Valley Water Management Agency, 2021, Pajaro Valley subbasin-Water year 2020 annual report: Pajaro Valley Water Management Agency, 38 p., accessed October 13, 2021, at https://www.pvwater.org/images/about-pvwma/ assets/annual_reports_assets/SGMA-WY/PVWater_AR_ WY2020.pdf.

Poland, J.F., ed., 1984, Guidebook to studies of land subsidence due to ground-water withdrawal: Paris, France, United Nations Educational, Scientific and Cultural Organization, 305 p., 5 appendixes, https://wwwrcamnl.wr.usgs.gov/rgws/Unesco/. 
Poland, J.F., and Ireland, R.L., 1988, Land Subsidence in the Santa Clara Valley, California, as of 1982: U.S. Geological Survey Professional Paper 497-F, 61 p., https://doi.org/10.3133/pp497F.

Riley, F.S., 1969, Analysis of borehole extensometer data from central California, in Tison, L.J., ed., Land Subsidence v. 2: Tokyo International Associaton of Science Hydrology Publication 89, p. 423-431.

Scripps Orbit and Permanent Array Center, 2019, ftp (file transfer protocol) website: Scripps Orbit and Permanent Array Center, accessed December 11, 2019, at ftp://garner.ucsd.edu/pub/timeseries/measures/ats/ WesternNorthAmerica/.

Sneed, M., and Brandt, J.T., 2020, Detection and measurement of land subsidence and uplift using Global Positioning System surveys and interferometric synthetic aperture radar, Coachella Valley, California, 2010-17: U.S. Geological Survey Scientific Investigations Report 2020-5093, 74 p., https://doi.org/10.3133/sir20205093.

Sneed, M., Brandt, J.T., and Solt, M., 2018, Land subsidence along the California Aqueduct in west-central San Joaquin Valley, California, 2003-10: U.S. Geological Survey Scientific Investigations Report 2018-5144, 67 p., https://doi.org/10.3133/sir20185144.
Tinsley, J.C., III, 1975, Quaternary geology of the northern Salinas Valley, Monterey County, California: Stanford, Calif., Stanford University, Ph.D. dissertation, 195 p., 2 sheets, scale 1:62,500.

Wahrhaftig, C., and Birman, J.H., 1965, The quaternary of the Pacific Mountain system in California, in Wright, H.E., Jr., and Frey, D.G., eds., The quaternary of the United States: Princeton University Press, p. 299-340, https://doi.org/10.1515/9781400876525-020.

Williams, S.D.P., Bock, Y., Fang, P., Jamason, P., Nikolaidis, R.M., Prawirodirdjo, L., Miller, M., and Johnson, D.J., 2004, Error analysis of continuous GPS position time series: Journal of Geophysical Research, v. 109, no. B3, 19 p., https://doi.org/10.1029/2003JB002741.

Zebker, H.A., Rosen, P.A., and Hensley, S., 1997, Atmospheric effects in interferometric synthetic aperture radar surface deformation and topographic maps: Journal of Geophysical Research, v. 102, no. B4, p. 7547-7563, https://doi.org/10.1029/96JB03804.

Zerbini, S., Richter, B., Negusini, M., Romagnoli, C., Simon, D., Domenichini, F., and Schwahn, W., 2001, Height and gravity variations by continuous GPS, gravity, and environmental parameter observations in the southern Po Plain, near Bologna, Italy: Earth and Planetary Science Letters, v. 192, no. 3, p. 267-279, https://doi.org/10.1016/S0012-821X(01)00445-9. 
For more information concerning the research in this report, contact the

Director, California Water Science Center

U.S. Geological Survey

6000 J Street, Placer Hall

Sacramento, California 95819

https://ca.water.usgs.gov

Publishing support provided by the U.S. Geological Survey Science Publishing Network, Sacramento Publishing Service Center 
얼

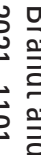

年

$\frac{\sqrt{0}}{0}$

https://doi.org/10.3133/ofr2021110 